The Open Dentistry Journal
CrossMark
Content list available at: www.benthamopen.com/TODENTJ/
DOI: $10.2174 / 1874210601610010188$

\title{
Antibacterial Activity of Copaiba Oil Gel on Dental Biofilm
}

\author{
Cláudia A.C.G. Simões ${ }^{1}$, Nikeila C. de Oliveira Conde $^{2}$, Gisely N. Venâncio ${ }^{3}$, Patrícia S.L.L. \\ Milério $^{4}$, Maria F.C.L. Bandeira, ${ }^{5, *}$ and Valdir F. da Veiga Júnior ${ }^{6}$ \\ ${ }^{I}$ Department of Dental Materials, College of Dentistry, UFAM - Federal University of Amazonas, Manaus, AM, Brazil \\ ${ }^{2}$ Department of Stomatology and Phytotherapy, College of Dentistry, UFAM - Federal University of Amazonas, \\ Manaus, AM, Brazil \\ ${ }^{3}$ Department of Stomatology and Phytotherapy, College of Dentistry, UFAM - Federal University of Amazonas, \\ Manaus, AM, Brazil \\ ${ }^{4}$ Department of Phytotherapy, College of Dentistry, UFAM - Federal University of Amazonas, Manaus, AM, Brazil \\ ${ }^{5}$ Department of Dentistry and Phytotherapy, College of Dentistry, UFAM - Federal University of Amazonas, Manaus, \\ AM, Brazil \\ ${ }^{6}$ School of Chemistry - Federal University of Amazonas, Manaus, AM, Brazil
}

Received: December 30, 2015

Revised: January 10, 2016

Accepted: January 28, 2016

\begin{abstract}
:
Amazonian biodiversity products that have been used for years in folk medicine, have emerged as feasible and promising alternatives for the inhibition of microorganisms in dental biofilm. Copaiba oil, a phytotherapic agent widely used by the Amazonian populations, is known for its antibacterial, anti-inflammatory, anesthetic, healing and antitumor medicinal properties.

Objective:

The aim of this study was to evaluate the in vitro antibacterial activity of copaiba oil (Copaifera multijuga) gel against strains of Streptococcus sp present in dental biofilm.

\section{Materials and Methods:}

The copaiba oil was obtained and the chemical components were identified. The oil emulsions were formulated and used with the Brain Heart Infusion agar diffusion method with strains of Streptococcus mitis, Streptococcus constellatus and Streptococcus salivarius isolated from patients as well as standard strains of S. mitis (ATCC903), S. mutans (ATCC10449), S. sanguinis (ATCC15300) and S. oralis (ATCC10557). The study groups were as follows: experimental copaiba oil gel, 1\% chlorhexidine gel (positive control) and base gel (negative control). The seeded plates were incubated at $37^{\circ} \mathrm{C}$ for 12,24 and 48 hours, respectively. The results obtained were analyzed by Shapiro-Wilk and Friedman Tests $(\mathrm{p}<0.05)$ for non parametric data and the Tukey test was used for $\mathrm{pH}$ values with $5 \%$ level of significance.
\end{abstract}

\section{Results:}

The experimental copaiba oil gel and $1 \%$ chlorhexidine gel showed antibacterial activity against the tested microorganisms.

\section{Conclusion:}

The copaiba oil gel demonstrated antibacterial activity against all the strains of Streptococcus sp tested, suggesting that it can be used for dental biofilm control.

Keywords: Alternative medicine, biofilm, Copaifera, phytotherapy, Streptococcus.

\footnotetext{
* Address correspondence to this author at the Department of Dentistry and Phytotherapy, College of Dentistry, UFAM - Federal University of Amazonas, Manaus, AM, Brazil; E-mail: fulgencia@ufam.edu.br
} 


\section{INTRODUCTION}

The term biofilm corresponds to one or more microbial communities imbibed in a matrix that covers a solid surface [1]. The way of controlling caries and periodontal disease is to prevent the formation of dental biofilm, or to remove it regularly [2].With the increasing incidence of oral diseases and development of antibiotic resistance, the global need for alternative treatment modalities, safe, effective, and economical products is important [3].

In the Amazon region of Brazil, many plants and their products are widely used in folk medicine, emerging as feasible and promising options for the inhibition of microorganisms in dental biofilm, Copaiba oil being one of these phytotherapic agents [4 - 6]. Copaiba (Copaifera multijuga Hayne) has great importance for the production of transparent, viscous and liquid oil-resin fluid obtained from its trunk. Its oils present local anesthetic, antiinflammatory, bactericidal, antitumor, healing, germicidal, expectorant,analgesic and antiviral activities [6 - 11]. The use of standardized extracts based on copaiba oleoresin can be an important strategy in the development of novel oral care products, since it can be considered for the control of periodontal diseases and dental caries [12].

Considering the national policy of integrative and complementary practices in the health system [13], and the possibility of introducing into dentistry, a phytotherapeutic product of Amazonian biodiversity, the aim of this study was to evaluate the in vitro antibacterial activity of copaiba oil (Copaifera multijuga) gel against strains of Streptococcus sp present on dental biofilm.

\section{MATERIALS AND METHODS}

The research was approved by the Research Ethics Committee of the Federal University of Amazonas under protocol number 02370712.8.0000.5020.

\section{Obtaining Copaiba Oil}

The Copaifera multijuga (CM) oil-resin used was obtained from the Reservation Ducke, of the National Institute of Amazonian Research, with exsiccate number 73 - a collection of dried specimens - deposited in the herbarium of this institution.

\section{Identification of Chemical Components and Formulation of Emulsions}

The constituents of copaiba oil were identified by Gas Chromatography coupled to a Flame Ionization Detector (GC-FID) and Mass Spectrometry Detector (CG-EM), according to the methodology related by Vasconcelos et al. [5]. $15]$.

The gel was formulated in the Pharmacy School of the Federal University of Amazonas. according to Brasil [13 -

\section{pH Determination}

The $\mathrm{pH}$ of the Copaiba oil gel was determined by potentiometer (TEC 2, TECNAL, Piracicaba, São Paulo, Brazil). The electrodes were connected to a potentiometer calibrated with standard solutions $\mathrm{pH} 7.0$ and 4.0 at $25{ }^{\circ} \mathrm{C}$, allowing linearity of the responses in relation to potential changes observed. The $\mathrm{pH}$ was determined at baseline (T0) and at 7 (T7), 30 (T30), 45 (T45) and 90 (T90) days in different storage locations: an oven, a refrigerator and at room temperature of $24^{\circ} \mathrm{C}-26^{\circ} \mathrm{C}$. The results corresponded to the average of three successive analyses [14].

\section{Microorganisms}

Strains of Streptococcus sp. were used, isolated from dental biofilm collected from patients resident in the city of Manaus, Amazonas, and identified; and standard strains of Streptococcus mutans (S. mutans) ATCC 25175 , Streptococcus sanguinis (S. sanguinis) ATCC 15300, Streptococcus mitis (S. mitis) ATCC 903 and Streptococcus oralis (S. oralis) ATCC 10557.

\section{Biofilm Sampling}

Dental biofilm samples were collected from four adult volunteers, aged between 21 and 35 years, of both genders, healthy, without systemic complications, who presented caries and gingivitis. Patients who presented periodontal disease at an advanced stage, dental prosthesis wearers, pregnant women, and patients who were using any type of medication were excluded from the study.

The supragingival biofilm formed was collected from the cervical third of all the teeth present in the oral cavity, 
using a sterile plastic spatula [16]. The samples collected were transferred to glass tubes with lids $(15 \mathrm{x} 1.5 \mathrm{~cm})$ containing $5 \mathrm{~mL}$ of $0.1 \mathrm{M}$ phosphate buffer solution, $\mathrm{pH} 7.4$, and glass pearls, sterilized and duly identified.

\section{Isolation of Strains of Streptococcus sp.}

The tubes were homogenized in a vortex (Thermolyne MaxiMix II M37615, Barnstead, Sparks, NV, USA) and afterwards serial dilutions of $10^{-1}$ a $10^{-5}$ were made in the same solution. An aliquot of the $10^{-5}$ dilution was taken for seeding by exhaustion on the surface of the selective medium for Streptococcus - Mitis Salivarius Agar / MAS (DIFCO, Kansas City, MO, USA). The Petri dishes (90x $150 \mathrm{~mm}$ ) were incubated under microaerophilic conditions at $37^{\circ} \mathrm{C}$ for 48 hours with bacterial growth being monitored every 12 hours [16].

\section{Identification of Bacteria}

The bacteria were isolated and the morphological characters were studied under an optical microscope (H600 Hund Wetzlar, Wetzlar, Germany). The microorganisms were identified by means of biochemical tests using the Api20 Strep kit (Bio Mérieux, Paris, France), in accordance with the manufacturer's instructions.

\section{Preparation of the Culture Media}

To test the antibacterial activity, agar B.H.I. (Brain Heart Infusion, DIFCO, Kansas City, MO, USA) and B.H.I. (DIFCO, Kansas City, MO, USA) enriched with 5\% horse blood were used, distributed into Petri dishes (90 x $150 \mathrm{~mm})$ and conserved in a refrigerator at $\pm 4^{\circ} \mathrm{C}$.

\section{Preparation of the Inoculum and Seeding the Plates}

Under aseptic conditions, the inoculum was prepared and standardized to \#0.5 of the McFarland scale. The inoculum was seeded by inundation on the culture medium in the Petri dishes.

\section{Preparing and Filling the Wells}

Three standardized wells, $1 \mathrm{~cm}$ in diameter by approximately $4 \mathrm{~mm}$ high were made in the culture medium, disposed at $1.5 \mathrm{~cm}$ from the edge of the well and at a distance of $3 \mathrm{~cm}$ between them, in order to prevent the inhibition haloes from meeting [4]. Using a sterile disposable syringe, $0.2 \mathrm{~mL}$ of the experimental gels were inserted into the wells, namely: Group I - experimental copaiba oil gel; Group II - 1\% chlorhexidine gel; Group III - base gel.

The plates were incubated under microaerophilic conditions at $37^{\circ} \mathrm{C}(12,24$ and 48 hours $)$ in a bacteriological oven BOD (Q315 M, Quimis, Diadema, SP, Brazil). The inhibition halo readouts were taken after 12 hours, using a stereoscopic loupe (Carl Zeiss do Brasil, São Paulo, SP, Brazil) for confirmation of the readouts. When there was no inhibition halo, the microorganism was considered resistant (R). Seven repetitions were performed for each microorganism and for each medium.

The data were submitted to the Shapiro-Wilk and Friedman Tests $(p<0.05)$ for non parametric data. In the evaluation of the $\mathrm{pH}$ the data were presented by means of tables with analysis of variance of $5 \%$ level of significance with comparison of means by Tukey test.

\section{RESULTS}

\section{Chromatographic Analysis}

The results of the chromatographic analysis of Copaifera multijuga oil revealed that the structures of its components are made up of various sesquiterpenes, basically being constituted of $\beta$-caryophyllene and its oxide.

\section{pH Determination}

The $\mathrm{pH}$ was determined and the results are presented in Table $\mathbf{1 .}$

Table 1. Mean pH values for the Copaiba oil gel according to local storage conditions and time (days)

\begin{tabular}{|c|c|c|c|c|c|}
\hline \multirow{2}{*}{ Storage location } & \multicolumn{5}{|c|}{ Time (days) } \\
\hline & $\mathbf{0}$ & 7 & 30 & 45 & 90 \\
\hline Oven & 6.68 & 6.57 & 6.62 & 6.56 & 6.39 \\
\hline Refrigerator & 6.68 & 6.6 & 6.67 & 6.7 & 6.67 \\
\hline
\end{tabular}


(Table $\square$ ) contd......

(Table 凹) contd.....
\begin{tabular}{|l|c|c|c|c|c|}
\hline \multirow{2}{*}{ Storage location } & $\mathbf{0}$ & $\mathbf{7}$ & $\mathbf{3 0}$ & $\mathbf{4 5}$ & $\mathbf{9 0}$ \\
\cline { 2 - 6 } & 6.68 & 6.67 & 6.65 & 6.7 & 6.66 \\
\hline Room temperature & $6.68 \mathrm{a}$ & $6.62 \mathrm{a}$ & $6.66 \mathrm{a}$ & $6.66^{\mathrm{a}}$ & $6.66 \mathrm{a}$ \\
\hline Mean & $($ days) \\
\hline
\end{tabular}

Means followed by same letters do not differ among them at the level of significance of $5 \%$.

\section{Antimicrobial Activity}

The results of the antibacterial activity are presented in Tables $\mathbf{2 , 3}$ and $\mathbf{4}$. The Shapiro-Wilk test $(p<0.05)$ was used for analyses. As the data did not follow a normal distribution, the Friedman test was used.

\section{Diffusion Test in Enriched BHI Culture Medium}

S. mutans presented antibacterial activity only in the period of 24 hours, being statistically significant in the experimental periods (Table 2).

Table 2. Means of $S$. mutans inhibition haloes (in $\mathrm{mm}$ ) in each time interval evaluated in enriched BHI medium.

\begin{tabular}{|c|c|c|}
\hline Time & Treatments & Inhibition (mm) \\
\hline 12 hours & Copaiba oil gel & $\mathrm{R}$ \\
\hline $\mathbf{2 4}$ hours & Chlorhexidine & 25.286 \\
\hline 48 hours & Copaiba oil gel & $\mathbf{9 . 5 0 0}$ a \\
\hline & Chlorhexidine & $26.000 \mathrm{~b}$ \\
\hline & Copaiba oil Gel & $\mathrm{R}$ \\
\hline
\end{tabular}

$\mathbf{R}=$ Resistant. $\mathbf{m m}=$ Millimeters. Means followed by different letters differ among them at the level of significance of $5 \%$.

\section{Diffusion Test in BHI Culture Medium}

Analyzing the antibacterial activity of the proposed gel, irrespective of the microorganisms and experimental time intervals, when comparing the results with the control, it was observed that in the time interval of 12 hours, no difference was found only for S. mitis (D4); for the other bacterial, chlorhexidine presented a higher mean value than the gel (Table 3).

Table 3. Antibacterial Activity of Copaiba oil gel and Chlorhexidine against the tested strains, showing the Means of inhibition haloes (in mm) at 12 hours in BHI medium.

\begin{tabular}{|c|c|c|c|}
\hline Bacteria & Treatments & Means (mm) & p-Value \\
\hline \multirow[t]{2}{*}{ S. constellatus } & Chlorhexidine & $20.17 \mathrm{a}$ & \multirow[t]{2}{*}{0.0039} \\
\hline & Copaiba oil gel & $16.57 \mathrm{~b}$ & \\
\hline \multirow[t]{2}{*}{ S. mitis ATCC 903} & Chlorhexidine & $23.00 \mathrm{a}$ & \multirow[t]{2}{*}{0.0004} \\
\hline & Copaiba oil gel & $20.43 \mathrm{~b}$ & \\
\hline \multirow[t]{2}{*}{ S. mitis D4 } & Chlorhexidine & $21.00 \mathrm{a}$ & \multirow[t]{2}{*}{0.0001} \\
\hline & Copaiba oil gel & $13.86 \mathrm{~b}$ & \\
\hline \multirow[t]{2}{*}{ S. mitis M3 } & Chlorhexidine & $22.00 \mathrm{a}$ & \multirow[t]{2}{*}{0.0001} \\
\hline & Copaiba oil gel & $12.86 \mathrm{~b}$ & \\
\hline \multirow[t]{2}{*}{ S. mitis $\mathrm{Fe} 4$} & Chlorhexidine & $23.14 \mathrm{a}$ & \multirow[t]{2}{*}{0.3639} \\
\hline & Copaiba oil gel & $22.00 \mathrm{a}$ & \\
\hline \multirow[t]{2}{*}{ S. oralis ATCC 10557} & Chlorhexidine & $20.21 \mathrm{a}$ & \multirow[t]{2}{*}{0.0001} \\
\hline & Copaiba oil gel & $13.57 \mathrm{~b}$ & \\
\hline \multirow[t]{2}{*}{ S. salivarius } & Chlorhexidine & $19.71 \mathrm{a}$ & \multirow[t]{2}{*}{0.009} \\
\hline & Copaiba oil gel & $14.28 \mathrm{~b}$ & \\
\hline \multirow[t]{2}{*}{ S. sanguinis ATCC 15300} & Chlorhexidine & $20.86 \mathrm{a}$ & \multirow[t]{2}{*}{0.0001} \\
\hline & Copaiba oil gel & $15.86 \mathrm{~b}$ & \\
\hline \multirow[t]{2}{*}{ S. mutans ATCC 25175} & Chlorhexidine & $20.18 \mathrm{a}$ & \multirow[t]{2}{*}{0.0001} \\
\hline & Copaiba oil gel & $14.85 \mathrm{~b}$ & \\
\hline
\end{tabular}

Mm = Millimeters. Means followed by different letters differ among them at the level of significance of 5\%.

In the time interval of 24 hours, no significant difference was observed between the results obtained with chlorhexidine and gel in the following bacteria: S. mitis (D4) and S. salivarius, and even in these two bacteria, 
chlorhexidine presented higher values than the gel. With the bacteria S. mitis (M3) - if it is admitted a level of significance of $5 \%$, it is possible to verify significant difference between chlorhexidine and the gel, with the gel being the agent that presented the highest haloes values (Table 4).

Table 4. Antibacterial Activity of Copaiba gel and Chlorhexidine against the tested strains, showing the Means of inhibition haloes (in mm) at 24 hours in BHI medium.

\begin{tabular}{|c|c|c|c|}
\hline Bacteria & Treatments & Means (mm) & p-Value \\
\hline \multirow[t]{2}{*}{ S. constellatus } & Chlorhexidine & $21.86 \mathrm{a}$ & \multirow[t]{2}{*}{0.016} \\
\hline & Copaiba oil gel & $16.71 \mathrm{~b}$ & \\
\hline \multirow[t]{2}{*}{ S. mitis ATCC 903} & Chlorhexidine & $23.21 \mathrm{a}$ & \multirow[t]{2}{*}{0.0079} \\
\hline & Copaiba oil gel & $21.28 \mathrm{~b}$ & \\
\hline \multirow[t]{2}{*}{ S. mitis D4 } & Chlorhexidine & $21.28 \mathrm{a}$ & \multirow[t]{2}{*}{0.3978} \\
\hline & Copaiba oil gel & $19.50 \mathrm{a}$ & \\
\hline \multirow[t]{2}{*}{ S. mitis M3 } & Chlorhexidine & $22.57 \mathrm{a}$ & \multirow[t]{2}{*}{0.0596} \\
\hline & Copaiba oil gel & $26.14 \mathrm{~b}$ & \\
\hline \multirow[t]{2}{*}{ S. mitis Fe4 } & Chlorhexidine & $24.14 \mathrm{a}$ & \multirow[t]{2}{*}{0.0004} \\
\hline & Copaiba oil gel & $20.28 \mathrm{~b}$ & \\
\hline \multirow[t]{2}{*}{ S. oralis ATCC 10557} & Chlorhexidine & $21.00 \mathrm{a}$ & \multirow[t]{2}{*}{0.0001} \\
\hline & Copaiba oil gel & $15.14 \mathrm{~b}$ & \\
\hline \multirow[t]{2}{*}{ S. salivarius } & Chlorhexidine & $21.14 \mathrm{a}$ & \multirow[t]{2}{*}{0.1113} \\
\hline & Copaiba oil gel & $17.21 \mathrm{a}$ & \\
\hline \multirow[t]{2}{*}{ S. sanguinis ATCC 15300} & Chlorhexidine & $22.43 \mathrm{a}$ & \multirow[t]{2}{*}{0.0001} \\
\hline & Copaiba oil gel & $13.57 \mathrm{~b}$ & \\
\hline \multirow[t]{2}{*}{ S. mutans ATCC 25175} & Chlorhexidine & $21.28 \mathrm{a}$ & \multirow[t]{2}{*}{0.0001} \\
\hline & Copaiba oil gel & $13.42 \mathrm{~b}$ & \\
\hline
\end{tabular}

$\mathbf{m m}=$ Millimeters. Means followed by different letters differ among them at the level of significance of 5\%.

The results of the multiple comparisons, in each group, were similar to those found for the other bacteria.

When analyzing the negative control (Group III) against all the microorganisms tested, treatments and experimental time intervals, there was no presence of inhibition haloes.

\section{DISCUSSION}

The chromatographic analysis showed that the structures of copaiba oil components are made up of various sesquiterpenes, basically being constituted of $\beta$-caryophyllene and its oxide. The same result was found by Bandeira $e t$ al. [4], Vasconcelos et al. [5] and Barbosa et al. [17], revealing a high proportion of sesquiterpenes $(88.55-98.05 \%)$ in the copaiba oils analysed, being the $\beta$-caryophyllene the principal type.

Studies have revealed that $\mathrm{pH}$ has an influence on bacterial growth. Depending on the $\mathrm{pH}$, there would be a growth in the availability of nutrients and an intense transference, which may induce inhibition and the toxic effects on the cells. Therefore, the enzymatic activity of the bacteria is inhibited under high $\mathrm{pH}$ conditions [18].

These factors lead us to believe that further studies must be conducted to seek the mechanism of action of the proposed gels in the tested microorganisms. Bacterial death depends on their conditions of growth and multiplication, and among these are physical-chemical factors such as: temperature, $\mathrm{pH}$, osmotic pressure, concentration of oxygen, carbon dioxide and substrate [19]. Studies have related that antibiotics cause two types of effects on bacteria: they may inhibit growth or reproduction, and they may be directed towards the bactericidal effect. Kohanski et al. [20] affirmed that these effects interfere in the synthesis of the cell wall, changing the cytoplasmic membrane permeability and interfering in protein synthesis.It is also important to analyze the effect of $\mathrm{pH}$ alone on bacterial cell growth, metabolism and division.

The antibacterial activity of the gels against the microorganisms tested may possibly be related to some chemical components present in the copaiba oil gel, a situation shown by Bandeira et al. [4], who demonstrated the antibacterial activity of calcium hydroxide and zinc oxide pastes associated with essential oil of Copaifera multijuga resin against S.mutans group and bacteriostatic and bactericidal activity of the oil in natura against the same microorganism. This fact was shown in this study in the evaluation of the antibacterial activity of the negative control and minimum bactericidal concentration (MBC) of the oil in natura. 
Furthermore, the low-pH environment at the tooth-biofilm interface results in enhanced demineralization of enamel, $\mathrm{pH} 5.5$ being considered the critical $\mathrm{pH}$. In this study, the $\mathrm{pH}$ of the copaiba oil gel presented a mean $\mathrm{pH}$ of 6.5 , considered neutral, therefore, does not contribute to the demineralization process.

Pieri et al. [6] evaluated the inhibitory activity of copaiba oil S. mutans using the serial dilution in broth technique and they concluded that copaiba oil showed a bacteriostatic activity against $S$. mutans at low concentrations as effective as $0.12 \%$ chlorhexidine, and could be an option of phytotherapic agent to be used against cariogenic bacteria in the prevention of caries disease. These authors affirmed that copaiba oil has advantages over chlorhexidine because it is composed by several different substances that may have different interactions with the bacterial cell, reducing the development of resistant $S$. mutans strains.

Another question of relevance for the results was the difficulty of gel diffusion in the culture medium, a similar problem faced by Bandeira et al. [4] with regard to copaiba oil diffusion in Agar medium. Siqueira Júnior, Gonçalves [21] observed the difficulty of calcium hydroxide diffusion in the same test, as calcium hydroxide has a low level of solubility in water, which limits its diffusibility. This fact leads us to infer that the copaiba gel presented the same difficulty due to its low diffusibility in Agar.

When comparing the results using the culture medium enriched with $5 \%$ horse blood and the culture medium without blood, one observed that enriched media had an influence on the antibacterial activity of the gel, because the unenriched medium provided better antibacterial activity. This may be related to the results found by Siqueira Júnior, Gonçalves [21], in which they observed that culture media, particularly those enriched with blood have a buffer capacity, which may cause a reduction in the high $\mathrm{pH}$ of calcium hydroxide making it less effective.

Moreover, the diffusion tests in agar may present a variation in the results, due to the variation in the density of columns, agar/material contact, speed of placement of the test material, which makes it difficult to reproduce the size of the inhibition haloes in daily practice [22].

In this research, it was observed that there was variability in the size of inhibition haloes. Moreover, in general, chlorhexidine presented inhibition haloes with larger sizes, which does not necessarily mean that it presented better antibacterial activity, bearing in mind that studies have found that the size of the inhibition halo does not necessarily reflects a higher or lower level of antibacterial effect, because it could be influenced by the size of the molecule, size of the inoculum, time of incubation, degree of contact between the material and culture medium, difficulty in reproducing the inhibition halo and diffusion capacity of the material in the culture medium [22, 23]. When evaluating the gel in isolation with regard to the oral bacteria, its performance presented a favorable perspective for the control of dental biofilm.

Vasconcelos et al. [5] assessed the antimicrobial activity of a dental cement containing Copaifera multijuga Hayne oleoresin against $S$. mutans and $S$. sanguinis by the dilution test in a liquid medium. Inhibition of microbial growth occurred in all tested groups of both bacterial species, showing that copaiba oil has great potential to be used in dental cement.

Studies of Pieri et al. [10] have also shown great potential for the use of copaiba oil in endodontic cement composition, as well as in the prevention and therapy of periodontal diseases. Thus, studies of Souza et al. [12] have demonstrated that the single diterpene (-) copalic acid, an important metabolite found in the oleoresin of Copaiba, is also very active against $S$. mutans. Therefore, these data denote that future oral care products containing this compound could be of great value for application in the treatment of control oral pathologies.

However, further researches must be conducted since in vitro tests do not allow us to extrapolate the data to an in vivo situation.Nevertheless, for ISO 7405, the improved development of in vitro tests has provided better correlation with the in vivo situation and has received considerable attention [24].

Copaiba oil in pharmaceutical formulations shows biological properties with perspectives for application on dental biofilm control, in addition to possibly contemplate integrative and complementary practices such as phythotherapy in the future.

\section{CONCLUSION}

The study demonstrated the antibacterial activity of the experimental copaiba oil gel against all the strains of Streptococcus sp tested, suggesting that it can be used in the future as a source of antimicrobials for dental biofilm control. 


\section{CONFILICT OF INTEREST}

The authors confirm that this article content has no conflict of interest.

\section{ACKNOWLEDGEMENTS}

This study was financed by National Council for Scientific and Technological Development - CNPq in Project MCT/CNPq/CT-Amazonia. Process No. 575752/2008-4.

\section{REFERENCES}

[1] Usha C, Sathyanarayanan R. Dental caries - A complete changeover (Part I). J Conserv Dent 2009; 12(2): $46-54$. [http://dx.doi.org/10.4103/0972-0707.55617] [PMID: 20617066]

[2] Sharma R, Reddy VK, Prashant G, Ojha V, Kumar NP. Antimicrobial and anti-adherence activity of various combinations of coffee-chicory solutions on Streptococcus mutans: An in-vitro study. J Oral Maxillofac Pathol 2014; 18(2): 201-6. [http://dx.doi.org/10.4103/0973-029X.140749] [PMID: 25328299]

[3] Karim B, Bhaskar DJ, Agali C, et al. Effect of Aloe vera mouthwash on periodontal health: triple blind randomized control trial. Oral Health Dent Manag 2014; 13(1): 14-9. [PMID: 24603910]

[4] Bandeira MF, Oliveira MR, Pizzolitto AC, Benatti Neto C. Estudo preliminar da atividade antibacteriana do óleo essencial e da resina da Copaifera multijuga (óleo de copaíba), associados ao óxido de zinco e ao hidróxido de cálcio. J Bras Clin Estet Odontol 1999; 3(17): 46-51.

[5] Vasconcelos KR, Veiga Júnior VF, Rocha WC, Bandeira MF. Avaliação in vitro da atividade antibacteriana de um cimento odontológico a base de óleo-resina de Copaifera multijuga Hayne. Rev Bras Farmacogn 2008; 18: 33-8. [http://dx.doi.org/10.1590/S0102-695X2008000500017]

[6] Pieri FA, Mussi MC, Fiorini JE, Moreira MA, Schneedorf JM. Bacteriostatic effect of copaiba oil (Copaifera officinalis) against Streptococcus mutans. Braz Dent J 2012; 23(1): 36-8. [http://dx.doi.org/10.1590/S0103-64402012000100006] [PMID: 22460312]

[7] Dias DS, Fontes LB, Crotti AE, et al. Copaiba oil suppresses inflammatory cytokines in splenocytes of C57B1/6 mice induced with experimental autoimmune encephalomyelitis (EAE). Molecules 2014; 19(8): 12814-26. [http://dx.doi.org/10.3390/molecules 190812814] [PMID: 25153880]

[8] Gomes NdeM, de Rezende CM, Fontes SP, Matheus ME, Pinto AdaC, Fernandes PD. Characterization of the antinociceptive and antiinflammatory activities of fractions obtained from Copaifera multijuga Hayne. J Ethnopharmacol 2010; 128(1): 177-83. [http://dx.doi.org/10.1016/j.jep.2010.01.005] [PMID: 20064592]

[9] Leandro LM, Vargas FdeS, Barbosa PC, Neves JK, da Silva JA, da Veiga-Junior VF. Chemistry and biological activities of terpenoids from copaiba (Copaifera spp.) oleoresins. Molecules 2012; 17(4): 3866-89. [http://dx.doi.org/10.3390/molecules17043866] [PMID: 22466849]

[10] Pieri FA, Mussi MC, Moreira MA. Óleo de copaíba (Copaifera sp.): histórico, extração, aplicações industriais e propriedades medicinais. Rev Bras Plant Med 2009; 11(4): 465-72. [http://dx.doi.org/10.1590/S1516-05722009000400016]

[11] Santos AO, Ueda-Nakamura T, Dias FBP, Veiga Jr VF, Pinto AC, Nakamura CV. Antimicrobial activity of Brazilian copaiba oils obtained from different species of the Copaifera genus. Mem Inst Oswaldo Cruz 2008; 103(3): 277-81. [http://dx.doi.org/10.1590/S0074-02762008005000015] [PMID: 18545856]

[12] Souza AB, de Souza MG, Moreira MA, et al. Antimicrobial evaluation of diterpenes from Copaifera langsdorffii oleoresin against periodontal anaerobic bacteria. Molecules 2011; 16(11): 9611-9. [http://dx.doi.org/10.3390/molecules16119611] [PMID: 22101836]

[13] Brasil. Agência Nacional de Vigilância Sanitária. Brasília: Brasil: Formulário de Fitoterápicos da Farmacopeia Brasileira 2011.

[14] Brasil. Agência Nacional de Vigilância Sanitária Resolução - RDC nº 17, de 16 de abril de 2010. Brasília: Brasil: Dispõe sobre as Boas Práticas de Fabricação de Medicamentos 2010.

[15] Brasil. Agência Nacional de Vigilância Sanitária. Resolução - RDC nº. 16, de 28 de março de 2013. In: Aprova o regulamento técnico de boas práticas de fabricação de produtos médicos e produtos para diagnóstico de uso in vitro e dá outras providências . Brasília: Brasil: Dispõe sobre as Boas Práticas de Fabricação de Medicamentos 2013.

[16] Caufield PW, Cutter GR, Dasanayake AP. Initial acquisition of mutans streptococci by infants: evidence for a discrete window of infectivity. J Dent Res 1993; 72(1): 37-45. [http://dx.doi.org/10.1177/00220345930720010501] [PMID: 8418105]

[17] Souza BPC, Moreira WLS, da Silva MR, de Tarso BSP, Vieira G, Florêncio da Veiga-Junior V. Phytochemical fingerprints of copaiba oils (Copaifera multijuga Hayne) determined by multivariate analysis. Chem Biodivers 2013; 10(7): 1350-60. [http://dx.doi.org/10.1002/cbdv.201200356] [PMID: 23847080]

[18] Yang KY, Haynes CA, Spatzal T, Rees DC, Howard JB. Turnover-dependent inactivation of the nitrogenase MoFe-protein at high pH. Biochemistry 2014; 53(2): 333-43. 
[http://dx.doi.org/10.1021/bi4014769] [PMID: 24392967]

[19] Hoehler TM, Jørgensen BB. Microbial life under extreme energy limitation. Nat Rev Microbiol 2013; 11(2): 83-94. [http://dx.doi.org/10.1038/nrmicro2939] [PMID: 23321532]

[20] Kohanski MA, Dwyer DJ, Collins JJ. How antibiotics kill bacteria: from targets to networks. Nat Rev Microbiol 2010; 8(6): $423-35$. [http://dx.doi.org/10.1038/nrmicro2333] [PMID: 20440275]

[21] Siqueira Júnior JF, Gonçalves RB. Antimicrobial activities of root canal sealers against selected anaerobic bacteria. J Endod 1996; 22: 79-80. [http://dx.doi.org/10.1016/S0099-2399(96)80277-9]

[22] Ostrosky EA, Mizumoto MK, Lima ME, Kaneko TM, Nishikawa SO, Freitas BR. Métodos para avaliação da atividade antimicrobiana e determinação da Concentração Mínima Inibitória (CMI) de plantas medicinais. Rev Bras Farm 2008; $18(2)$ : $301-7$. [http://dx.doi.org/10.1590/S0102-695X2008000200026]

[23] Pinto TJ, Kaneko TM, Ohara MT. Controle biológico de qualidade de produtos farmacêuticos, correlatos e cosméticos 2. São Paulo: Atheneu 2003.

[24] ISO 7405: Dentistry - preclinical evaluation of biocompatibility of medical devices used in dentistry - test methods for dental materials. Geneva: The Organization 2008.

C Simões et al. ; Licensee Bentham Open.

This is an open access article licensed under the terms of the Creative Commons Attribution-Non-Commercial 4.0 International Public License (CC BY-NC 4.0) (https://creativecommons.org/licenses/by-nc/4.0/legalcode), which permits unrestricted, non-commercial use, distribution and reproduction in any medium, provided the work is properly cited. 